\title{
Physiotherapy in Bruxism: A Scoping Review
}

\author{
Krina Savla', Vishnu Vardhan', Diksha Aage ${ }^{3}$ \\ ${ }^{1}$ BPT Student, Dr. A.P.J. Abdul Kalam College of Physiotherapy, Loni, Maharashtra. \\ ${ }^{2}$ Associate Professor Cardiorespiratory Department, Dr. A.P.J. Abdul Kalam College of Physiotherapy \\ ${ }^{3}$ Assistant Professor Pediatric Physiotherapy, Dr. A.P.J. Abdul Kalam College of Physiotherapy \\ Corresponding Author: Krina Dhiren Savla
}

\begin{abstract}
Background: Bruxism is a parafunctional activity comprising of spasmodic non-functional gnashing, grinding, or clenching of teeth or involuntary rhythmic movement which may cause occlusal trauma. Bruxism causes muscular pain, stiffness, jaw restriction, sleep disturbances and degraded quality of life. The awareness of bruxism in population is extremely low. Physiotherapy has proven effective in many musculoskeletal and neurological conditions as a non-pharmacological treatment. Thus, the aim of this study to explore the recent physiotherapy treatments available for the better prognosis and improved quality of life for the patient suffering from bruxism.

Methodology: In this scoping review articles are researched from the search engines like PUBMED, GOOGLE SCHOLAR, etc. These articles are reviewed according to the inclusion criteria which include last 5 years of articles, experimental and clinical trials, randomized and non-randomized control trials, etc. 9 articles were selected according to it. Later the qualities of these articles were analyzed with help of PEDRO Scale.

Conclusion: Pain, muscle activity reduction and increase jaw mobility are the key symptoms to be focused on by physiotherapy management. Physiotherapy has recently provided different techniques like Kinesiotaping and dry needling effective, myofascial trigger point release in reducing pain in bruxism. There are modalities like contingent electrical stimulation which help in reducing episodes, low level laser therapy reduces bruxism pain. Exercises and relaxation and PNF techniques and massage therapy all help in increasing the range of motion, strengthening, pain reduction, better oral and sleep habits. More research needs to be done on effect of different stretching on bruxism. Overall a combination of this management can provide a better and quality treatment for Bruxism.
\end{abstract}

Keywords: Bruxism, Physiotherapy.

\section{INTRODUCTION}

Bruxism is a parafunctional activity comprising of spasmodic non-functional gnashing, grinding, or clenching of teeth or involuntary rhythmic movement which may cause occlusal trauma. ${ }^{1,2}$ It is a repetitive jaw muscle activity which do not have functional objectives like mastication, phonation and swallowing. It is an oral habit which is differentiated with two types (1) Awake Bruxism (AB) also called Diurnal Bruxism which occurs predominately in the consciously awake time. It is usually due to anxiety and low stress coping response. ${ }^{3}$
Sleep Bruxism (SB) is a movement disorder which is evident while non-REM sleep or nocturnally labeling as parasomnia. ${ }^{1,4}$

The awareness of bruxism is quite less in the population, the prevalence varies ranging from $5 \%$ to $90 \%$, approximately $20 \%$ in adults, $13 \%$ in adolescents, $14-20 \%$ in children and $3 \%$ in elderly all over the world. Prevalence in Dutch population 5$16 \%$ and in Brazil 31\%., 6 The incidence of Sleep Bruxism (SB) in adults varies from $3 \% \pm 13 \%$ and Awake Bruxism (AB) in adults varies from $22 \% \pm 31 \%$. There is no evidence of any genetic marker for bruxism 
but Awake Bruxism (AB) has a considerable higher rate in females and younger individuals. ${ }^{7,8}$ A Study on 12-15year-old adolescents of Faridabad state, India from concluded $92(30.7 \%)$ out of which $56 \%$ were mild, $19 \%$ moderate, $10 \%$ severe bruxism. ${ }^{9}$ Another study suggested the prevalence of self-reported diurnal bruxism among information technology (IT) professionals was $59 \%$ Bangalore, India. ${ }^{10}$

In adults with social anxiety disorder, emotional stress, heavy smoking, and excessive alcohol consumption are at high risk of bruxism. Lower age, female gender, caffeine usage, psychosocial factors, depression, sleep disorders (e.g. obstructive sleep apnea), genetics and medications have higher chances of experiencing bruxism. Children and adolescents with behavioral disorders, Attention deficit hyperactive disorder (ADHD), somniloquy are at higher risk of bruxism. Bad night sleep, late night media consumption also affects bruxism in children. $^{11,12}$

Bruxism involves the repetitive activity of muscles for jaw opening muscles like digastric and jaw closing muscles like masseter, temporalis, medial and lateral pterygoids. During sleep the muscle tone reduces and spontaneous rhythmic masticatory muscle activity (RMMA), occurs once or twice per hour in normal population but increases in bruxers. These activity are caused by transient increase in electrical activity of brainstem central pattern generator (CPG) consisting of a neuronal network that produces alternate jaw movements. ${ }^{13}$ The oral parafunctional activity (bruxism) shows muscle hyperactivity of masseteric sling muscle resulting in myalgia, muscle spasm and in long term hypertrophic masseter. Patients with sleep bruxism have significantly diagnosed with temporomandibular disorders (TMDs) and temporal headaches, and chronic episodic migraine and tension type headache. Temporomandibular disorders (TMD) symptoms include muscle and joint pain, morning muscle pain, stiffness, joint noises headaches and jaw locking. These symptoms elicit vertigo, tinnitus and auditory changes worsening with Awake Bruxism (AB). Clinically bruxers perceived with damage to tooth structure including fractured teeth, hair line cracks and restorations, weared facets, abfractive lesions, and eventually loss of teeth. Periodontal changes, including widening of the periodontal ligament, tooth mobility, and recession, oral soft tissue and jawbone changes are also observed. ${ }^{8}$

Mechanism for bruxism and temporomandibular disorders is a biopsychosocial framework consisting of stress sensitivity and anxious personality traits related to increase temporomandibular pain. Sleep Bruxism (SB) and Awake Bruxism $(\mathrm{AB})$ have different reasons of pain in clenching and grinding motor phenomenon resulting in muscle fatigue and joint stress. Myofascial pain is related to sleep bruxism with a cause-effect view where sustained elevated muscle activity (SEMA) causes transient pain. Isometric persistent high intensity bruxism may trigger temporomandibular pain, if onset of the pain is early, protective response reduces the muscle activity for recovery leading to spasm. ${ }^{14},{ }^{15}$ Bruxers with temporomandibular disorders (TMD) complained of tightness and pressure pain over the frontotemporal area. This can be proposed on the hypothesis that the nociceptive stimulus from the temporomandibular joint (TMJ) and masticatory muscles increase the excitability or central sensitization of trigeminal subnucleus caudalis nociceptive neuron which prompts generalized pain. ${ }^{16}$ Recurrent headaches and masticatory muscle tenderness caused by over activity of muscle in bruxers lead to hypermobility of jaw. ${ }^{17}$ Bruxers during a triangular bite force task show greater jaw tremor at $\sim 8 \mathrm{~Hz}$ relative to controls. The measurement of tremor in bruxism may require higher forces rather than normal, with more importance to the dynamics of bite force production. ${ }^{18}$

Lobbezoo et al. proposed a grading system for clinical diagnosis of bruxism. 
The subcategorized bruxism into "possible" "probable" and "definite" bruxism. Based on "probable" with self-reported questionnaire, if with even clinical investigation then "possible" bruxism. "Definite" bruxism is suggested with polysomnography or video. American Academy of Sleep Medicine (AASM) proposed a diagnostic criteria of sleep bruxism updated on the International Classification of Sleep Disorder (ICSD) which is a clinical protocol based on one or more of these symptoms. Abnormal wearing of tooth with sleep grinding or momentary morning jaw pain or fatigues or temporal headaches or jaw locking. ${ }^{19}$ The gold standard for investigating bruxism is the recording of electromyography (EMG) activity during sleep (polysomnography). ${ }^{18}$

Polysomnography is expensive, while takes more time for observation and labour intensive and due to laboratory setup is unable to monitor oral hygiene. Portable electromyography (EMG) with Electrocardiogram is used which is slightly less accurate than polysomnography. ${ }^{20} \mathrm{~A}$ combination of thoracic activity and body position, electro- encephalography, electrooculography, with cardiac and muscular monitoring is helpful in diagnosing Sleep Bruxism events. ${ }^{21}$

Bruxism is treated conservatively mainly by reducing the muscle activity and managing pain. To Decrease the risk of causing crazy lines and restorations and reducing the frequency of Awake Bruxism (AB) for even decreasing pain. Even the damage in Sleep Bruxism (SB) can be prevented with occlusal guard. The "Multiple-P" approach with pep talks, plates and pills, psychology, physiotherapy. This includes the psychological counselling, occlusal stabilizing splint, and short-term pharmacological therapy. The psychosocial component include stress reduction therapy, lifestyle changes, counseling, and hypnotherapy. ${ }^{8,11,22}$ Techniques like muscle relaxation and reaction competence can be used to reduce jaw muscular activity and anxiety have been proven beneficial. ${ }^{23}$
Behavior modification such as habit attentiveness, habit reversal therapy, relaxation techniques and biofeedback therapy. Patient awareness is increased by giving cards to be pasted in their regular visible places with note stating to "Lips together, teeth apart" 8,11 Reduction in sleep habit like snoring, restless sleep, mouth breathing, drooling, lack of sleep, stomach position during sleep facilitates decreasing bruxism. ${ }^{24}$ The occlusal therapy are made of hard acrylic splint, NTI-tss devices. Pharmacological interventions include muscle relaxers and botulinum toxin injections into to muscles involved. Botulinum toxin reduces the intensity whereas not that effective in reducing frequency or muscle pain level. Neuroleptic drug gabapentin in patients with poor sleep quality has proven effective. Benzodiazepine clonazepam and antihypertensive clonidine which act centrally on nervous system are effective in reducing sleep bruxism whereas peripherally acting drugs are not that effective. ${ }^{8,11}$ Recent study states Librium, which contains cholrdiazepoxide $\mathrm{HCl}$ has antianxiety, appetite stimulating, sedative and weak analgesic action. It relieves jaw pain and tenderness and improves the quality of life. It shortens the duration of bruxism episodes by blocking the Electroencephalogram (EEG) arousal from stimulation of the reticular formation in brainstem. ${ }^{23}$ Physical Therapy has been used to treat several musculoskeletal and neurological conditions. Some studies have included the use of manual therapy, relaxation therapies, electrotherapy, kinesiotaping, cognitive behavioral therapy, postural awareness in treatment of bruxism. Symptomatic management with the help of physical therapy is also been effective in pain reduction and increasing the range of motion with short-term relief. ${ }^{22}$ A study of the effect of patient in masticatory muscle pain with encouragement, self-education, stretching, jaw relaxation, exercises and home advice was assessed which suggested faster reduction in pain intensity and 
increase in functions of the muscle in early management. Patient education and counselling related to the importance of patient and psychology is crucial for improvement of patient quality of life in temporomandibular disorders (TMD). Physiotherapy influences the pain intensity, inability, self- confidence, fear of movement and reinjury. ${ }^{25}$ There are various physiotherapy treatment for the management of Bruxism which we will discuss further ahead.

\section{METHODOLOGY}

Study setting: Dr. A. P. J. Abdul Kalam College of Physiotherapy, Loni

Study Design: Scoping Review. This Scoping Review is a technique to 'map' relevant evident based literature in the field of interest.

Database and Search Strategy: The search will be done on Search Engines: PUBMED, Google Scholar, CINAHL, PEDro. The key words which will be used for the research are: Bruxism, Physical Therapy, Awake Bruxism and Sleep Bruxism.

Study Duration: 6 months

Equipment to be used: Laptop.

Selection Criteria: Information sources will be independently used to search articles. The relevance of the article to the research question is been observed before reviewing it. The articles for review will be selected according to their inclusion or exclusion in the criteria set. The full text of the article will be reviewed by the coinvestigator and the considerable relevance of the article will be considered for deciding if the article should be reviewed.

\section{Eligibility Criteria:}

Phenomenon of Interest: Physiotherapy in Bruxism

\section{Inclusion Criteria ${ }^{2,22}$ :}

1. Articles from last 5 years

2. Articles published in English

3. Articles with abstract and Full text available
4. Experimental Study

5. Randomised and Non Randomised control trial

6. Pre-test/ Post-test

7. Comparison study

8. Sleep and Awake Bruxism

9. TMD and Headache

Exclusion Criteria ${ }^{2,22}$ :

1. No Geographic restriction

2. Descriptive Study

3. Abstract and Poster

4. Medical and other than physiotherapy management

\section{PROCEDURE}

Evidence based articles elaborating the objectives of the study will be selected for scoping review, data will be collected on the bases of eligibility criteria from the selected sites and index. The quality of the articles are assessed and the articles are discussed and drawing a conclusion for the study.

\begin{tabular}{|l|l|l|l|}
\multicolumn{5}{|c|}{ Table: 1 } \\
\begin{tabular}{|l} 
Search \\
Engine
\end{tabular} & Search Topic & $\begin{array}{l}\text { No. } \\
\text { articles } \\
\text { present }\end{array}$ & $\begin{array}{l}\text { No. } \\
\text { articles } \\
\text { selected }\end{array}$ \\
\hline Pubmed & Bruxism & 4002 & 0 \\
\hline & $\begin{array}{l}\text { Bruxism, } \\
\text { Physical } \\
\text { Therapy }\end{array}$ & 141 & 3 \\
\hline $\begin{array}{l}\text { Google } \\
\text { Scholar }\end{array}$ & $\begin{array}{l}\text { Bruxism, } \\
\text { Physical } \\
\text { Therapy }\end{array}$ & 14300 & 6 \\
\hline
\end{tabular}

\section{Outcome Measures:}

Physiotherapy Evidence Database (PEDro) scale is a 10 component scale to assess the methodological quality of clinical trial. It is also used to rate systematic reviews. The PEDro scale was developed from Delphi List. As per author's suggestion the scores are: $<4$ is reflected 'poor', 4-5 is fair, 6-8 is 'good' and 9-10 is 'excellent'. Eligibility criteria are not countable. The Inter-rater reliability of this PEDro scale is $\mathrm{ICC}=0.53$ to 0.91 for clinical trial of physiotherapy related intervention. $^{26}$ 
Table:2

\begin{tabular}{|c|c|c|c|c|c|c|c|c|c|}
\hline Author & $\begin{array}{l}\text { Gouw } \\
\text { S, et. } \\
\text { al }^{27}\end{array}$ & $\begin{array}{l}\text { Keskinruzgar } \\
\text { A, et.al }\end{array}$ & $\begin{array}{l}\text { Blasco- } \\
\text { Bonora } \\
\text { PM, et.al }^{29}\end{array}$ & $\begin{array}{l}\text { Yazici } \\
\text { G,et.al }^{30}\end{array}$ & $\begin{array}{l}\text { Calisgan } \mathrm{E}, \\
\text { et.al }^{31}\end{array}$ & $\begin{array}{l}\text { Sya } \\
\text { A,et.al }^{32}\end{array}$ & $\begin{array}{l}\text { Lietz- } \\
\text { Kijak } \\
\text { D, et.al }^{33}\end{array}$ & $\begin{array}{l}\text { Quaresma } \\
\text { MC, } \\
\text { et.al }^{34}\end{array}$ & $\begin{array}{l}\text { Rathi } \\
\text { M, } \\
\text { et.al }^{35}\end{array}$ \\
\hline $\begin{array}{l}\text { Random } \\
\text { allocation }\end{array}$ & Yes & Yes & No & Yes & Yes & Yes & Yes & Yes & Yes \\
\hline $\begin{array}{l}\text { Concealed } \\
\text { allocation }\end{array}$ & Yes & Yes & No & No & Yes & No & No & Yes & No \\
\hline $\begin{array}{l}\text { Baseline } \\
\text { characteristics } \\
\text { comparable } \\
\end{array}$ & Yes & Yes & Yes & Yes & Yes & Yes & Yes & Yes & Yes \\
\hline Subject blinded & No & No & Yes & Yes & No & No & No & No & No \\
\hline Therapist blinded & No & No & No & Yes & No & No & No & No & No \\
\hline Assessor blinded & Yes & No & Yes & Yes & No & No & No & Yes & No \\
\hline $\begin{array}{l}\text { Outcome for } \\
85 \% \text { of initial } \\
\text { participants }\end{array}$ & Yes & Yes & Yes & Yes & Yes & Yes & Yes & Yes & Yes \\
\hline Intention to treat & Yes & Yes & Yes & Yes & Yes & Yes & Yes & Yes & Yes \\
\hline $\begin{array}{l}\text { Comparison } \\
\text { between } \\
\text { group statistical }\end{array}$ & Yes & Yes & Yes & No & Yes & Yes & Yes & Yes & Yes \\
\hline Point variability & Yes & Yes & Yes & Yes & Yes & Yes & Yes & Yes & Yes \\
\hline Total score & $08 / 10$ & $07 / 10$ & $07 / 10$ & $08 / 10$ & $07 / 10$ & $06 / 10$ & $06 / 10$ & $08 / 10$ & $06 / 10$ \\
\hline
\end{tabular}

\section{RESULT}

Table: 3

\begin{tabular}{|c|c|c|c|c|c|c|}
\hline Author & Year & Topic & Objective & $\begin{array}{l}\text { Sample } \\
\text { size }\end{array}$ & Outcome measures & Conclusion \\
\hline $\begin{array}{l}\text { Gouw } \\
\text { S, et.al }\end{array}$ & 2018 & $\begin{array}{l}\text { Masticatory muscle } \\
\text { stretching for the } \\
\text { management of } \\
\text { sleep bruxism: a } \\
\text { randomised control } \\
\text { trial }\end{array}$ & $\begin{array}{l}\text { To determine the } \\
\text { effectiveness of } \\
\text { stretching of the } \\
\text { masticatory muscles } \\
\text { for sleep bruxism. }\end{array}$ & 24 & $\begin{array}{l}\text { The outcome measures were } \\
\text { based on the Graded Chronic } \\
\text { Pain Scale (GCPS) and the } \\
\text { Mandibular } \\
\text { Impairment Function } \\
\text { (MFIQ). Clinically examination } \\
\text { with measuring the mandibular } \\
\text { range of motion (ROM) with a } \\
\text { millimeter ruler, maximum } \\
\text { voluntary bite force by a } \\
\text { calibrated tensile tester, and } \\
\text { pain threshold and tolerance } \\
\text { with the Wagner algometer. } \\
\text { The sleep quality was also } \\
\text { assessed. The bruxism episodes } \\
\text { were daily reported with } \\
\text { polysomnography. }\end{array}$ & $\begin{array}{l}\text { Static stretching is not } \\
\text { effective in relieving } \\
\text { bruxism. }\end{array}$ \\
\hline $\begin{array}{l}\text { Keskinruzgar } \\
\text { A, et.al }\end{array}$ & 2018 & $\begin{array}{l}\text { Comparison of } \\
\text { kinesiotaping and } \\
\text { occlusal splint in } \\
\text { the management of } \\
\text { myofascial pain in } \\
\text { the patients with } \\
\text { sleep bruxism }\end{array}$ & $\begin{array}{l}\text { To evaluate the } \\
\text { efficacy of Kinesio } \\
\text { taping (KT) in patients } \\
\text { with sleep bruxism } \\
\text { (SB) and to determine } \\
\text { whether } \\
\text { KT may be an } \\
\text { alternative for occlusal } \\
\text { splint (OS) for the } \\
\text { treatment of SB }\end{array}$ & 34 & $\begin{array}{l}\text { The participants were clinically } \\
\text { examined for bruxism. The } \\
\text { outcome measures were Visual } \\
\text { Analogue Scale (VAS), } \\
\text { Pressure pain threshold of } \\
\text { temporalis and bilateral } \\
\text { massester muscle and the } \\
\text { mouth opening measurement. }\end{array}$ & $\begin{array}{l}\text { OS and KT are } \\
\text { equally effective in } \\
\text { patients with bruxism. } \\
\text { KT is effective in } \\
\text { reducing muscle pain } \\
\text { and increasing mouth } \\
\text { opening size. KT can } \\
\text { be used as an ideal } \\
\text { treatment in the } \\
\text { patients were OS is } \\
\text { contraindicated. }\end{array}$ \\
\hline $\begin{array}{l}\text { Blasco- } \\
\text { Bonora PM, } \\
\text { et.al }^{29}\end{array}$ & 2016 & $\begin{array}{l}\text { Effect of } \\
\text { myofascial trigger } \\
\text { point dry needling } \\
\text { in the patients with } \\
\text { sleep bruxism and } \\
\text { temporomandibular } \\
\text { disorders: a } \\
\text { prospective case } \\
\text { series }\end{array}$ & $\begin{array}{l}\text { To investigate the } \\
\text { effects of deep dry } \\
\text { needling (DN) of } \\
\text { myofascial trigger } \\
\text { points (MTrPs) of the } \\
\text { masseter and } \\
\text { temporalis on pain, } \\
\text { pressure pain threshold } \\
\text { (PPT), pain-free } \\
\text { maximal jaw opening } \\
\text { and terale } \\
\text { temporomandibular } \\
\text { disorder (TMD)-related } \\
\text { disability in patients } \\
\text { with sleep bruxism } \\
\text { (SB) and myofascial } \\
\text { TMD. }\end{array}$ & 23 & $\begin{array}{l}\text { The outcome measures were } \\
\text { Visual Analogue Scale (VAS), } \\
\text { mouth opening measured with } \\
\text { a ruler, Pressure pain threshold } \\
\text { (PPT) measured with an } \\
\text { algometer and jaw disability } \\
\text { checklist (JDC) questioner. }\end{array}$ & $\begin{array}{l}\text { Application of Dry } \\
\text { needling resulted in } \\
\text { reduction of pain, } \\
\text { tenderness and had } \\
\text { maximal jaw opening } \\
\text { and functioning } \\
\text { immediately after the } \\
\text { treatment and one } \\
\text { week later. }\end{array}$ \\
\hline
\end{tabular}




\begin{tabular}{|c|c|c|c|c|c|c|}
\hline \multicolumn{7}{|c|}{ Table:2 Continued... } \\
\hline $\begin{array}{ll}\text { Yazici } & \text { G, } \\
\text { et.al }^{30}\end{array}$ & 2020 & $\begin{array}{l}\text { Evaluation of } \\
\text { single session } \\
\text { physical therapy } \\
\text { method in bruxism } \\
\text { patients using shear } \\
\text { wave } \\
\text { ultrasonography }\end{array}$ & $\begin{array}{l}\text { To compare the } \\
\text { immediate effects of a } \\
\text { single session of } \\
\text { manual therapy (MT) } \\
\text { or Kinesiotaping } \\
\text { following MT (KTMT) } \\
\text { in patients with } \\
\text { bruxism using shear } \\
\text { wave ultrasonography. }\end{array}$ & 39 & $\begin{array}{l}\text { Effect of the treatment on } \\
\text { muscle thickness was observed } \\
\text { with shear wave } \\
\text { ultrasonography and muscle } \\
\text { stiffness with SWE. Pressure } \\
\text { pain threshold was examined } \\
\text { on MTrP with an algometer. }\end{array}$ & $\begin{array}{l}\text { There is a visible } \\
\text { effect of MT on } \\
\text { muscular parameter on } \\
\text { one session stating a } \\
\text { long term use can be } \\
\text { more effective. The } \\
\text { KT is an additional } \\
\text { technique which main } \\
\text { emphasis is on pain } \\
\text { reduction. KTMT is } \\
\text { more effective then } \\
\text { only MT as muscle } \\
\text { activity and pain both } \\
\text { are managed together. }\end{array}$ \\
\hline $\begin{array}{l}\text { Calisgan } \mathrm{E}, \\
\mathrm{et.al}^{31}\end{array}$ & 2018 & $\begin{array}{l}\text { The effect of } \\
\text { proprioceptive } \\
\text { neuromuscular } \\
\text { facilitation, } \\
\text { myofascial } \\
\text { releasing } \\
\text { maneuvers and } \\
\text { home exercises on } \\
\text { pain and jaw } \\
\text { function in patients } \\
\text { with bruxism }\end{array}$ & $\begin{array}{l}\text { Evaluate the effects } \\
\text { of proprioceptive } \\
\text { neuromuscular } \\
\text { facilitation exercises, } \\
\text { myofascial } \\
\text { releasing maneuvers } \\
\text { and home exercises on } \\
\text { temporomandibular } \\
\text { joint pain and jaw } \\
\text { function in patients } \\
\text { with bruxism. }\end{array}$ & 32 & $\begin{array}{l}\text { The patients were evaluated } \\
\text { with Visual Analogue Scale } \\
\text { (VAS), Jaw restriction scale } \\
\text { and oral habit checklist. }\end{array}$ & $\begin{array}{l}\text { The combination of } \\
\text { the PNF, MTrP and } \\
\text { home exercise have } \\
\text { effective reduction in } \\
\text { pain of TMJ, oral } \\
\text { habits with increase } \\
\text { jaw mobility. } \\
\text { Myofascial relaxation } \\
\text { with home exercise } \\
\text { also is effective in } \\
\text { reducing bruxism. } \\
\text { Head and neck } \\
\text { strengthening } \\
\text { increases } \\
\text { behaviour. }\end{array}$ \\
\hline Sya A, et.al ${ }^{32}$ & 2020 & $\begin{array}{l}\text { The effect of Low } \\
\text { level LASER, } \\
\text { BOTAX, and } \\
\text { occulsal splints in } \\
\text { the treatment of } \\
\text { muscle pain of } \\
\text { bruxism using } \\
\text { electromyography }\end{array}$ & $\begin{array}{l}\text { To assess the effect of } \\
\text { low level LASER } \\
\text { therapy, BOTAX, and } \\
\text { occlusal splints using } \\
\text { electromyogram on } \\
\text { muscle activity in } \\
\text { management of muscle } \\
\text { pain of bruxism. }\end{array}$ & 120 & $\begin{array}{l}\text { The muscle activity after } \\
\text { different treatment is evaluated } \\
\text { with electromyography on } \\
\text { temporalis and masseter } \\
\text { muscle. }\end{array}$ & $\begin{array}{l}\text { The study stated that } \\
\text { all the groups showed } \\
\text { significant difference } \\
\text { of muscle activity } \\
\text { after the treatment at } \\
\text { all intervals. The Low } \\
\text { level LASER was } \\
\text { effective in reducing } \\
\text { the pain intensity. } \\
\text { BOTAX treatment } \\
\text { showed immediate } \\
\text { respond in the muscle } \\
\text { activity but reduced in } \\
\text { long term. The } \\
\text { splinting was effective } \\
\text { in patients only till the } \\
\text { patients } \\
\text { continuously using the } \\
\text { splints. Thus the study } \\
\text { showed BOTAX as a } \\
\text { classical treatment and } \\
\text { LASER as a long term } \\
\text { effective treatment. }\end{array}$ \\
\hline $\begin{array}{l}\text { Lietz- Kijak } \\
\text { D, et.al }{ }^{33}\end{array}$ & 2018 & $\begin{array}{l}\text { Assessment of the } \\
\text { short term } \\
\text { effectiveness of } \\
\text { kinesiotaping and } \\
\text { trigger point } \\
\text { release used in } \\
\text { functional } \\
\text { disorders of the } \\
\text { masticatory muscle }\end{array}$ & $\begin{array}{l}\text { To evaluate the effect } \\
\text { of the kinesiotaping } \\
\text { method and trigger } \\
\text { points inactivation on } \\
\text { the } \\
\text { pharmacological non- } \\
\text { elimination of pain in } \\
\text { patients in functional } \\
\text { disorders } \\
\text { mastication. }\end{array}$ & 60 & $\begin{array}{l}\text { It is a short term study which } \\
\text { records the pain intensity with } \\
\text { Visual Analogue Scale (VAS) } \\
\text { before the treatment and } \\
\text { immediately after the } \\
\text { treatment. }\end{array}$ & $\begin{array}{l}\text { The importance of this } \\
\text { study was the } \\
\text { analgesic effect } \\
\text { provided instantly } \\
\text { with the treatment. } \\
\text { Both the KT and } \\
\text { MTrP have a } \\
\text { significant decrease in } \\
\text { the intensity of pain. } \\
\text { But KT provides } \\
\text { better pain relief. If } \\
\text { the short term } \\
\text { effectiveness of this } \\
\text { treatment is } \\
\text { appreciable then the } \\
\text { clinical use with other } \\
\text { physical therapeutic } \\
\text { exercises will provide } \\
\text { better results. There is } \\
\text { no age related } \\
\text { preference or changes } \\
\text { in the treatment. }\end{array}$ \\
\hline
\end{tabular}




\begin{tabular}{|c|c|c|c|c|c|c|}
\hline \multicolumn{7}{|c|}{ Table:2 Continued... } \\
\hline $\begin{array}{l}\text { Quaresma } \\
\text { MC, et.al }{ }^{34}\end{array}$ & 2020 & $\begin{array}{l}\text { Effect } \\
\text { contingent } \\
\text { electrical } \\
\text { stimulation in sleep } \\
\text { bruxism: } \\
\text { randomized } \\
\text { clinical trial }\end{array}$ & $\begin{array}{l}\text { The effects of a 4- and } \\
\text { 8-week consecutive use } \\
\text { of contingent electrical } \\
\text { stimulation on self- } \\
\text { reported pain, jaw } \\
\text { muscle activity, and } \\
\text { threshold intensity in } \\
\text { teeth grinding during } \\
\text { sleep, over } 6 \text { months. }\end{array}$ & 48 & $\begin{array}{l}\text { The outcome measures } \\
\text { considered are the number of } \\
\text { grinding episodes per night by } \\
\text { Electromyographic monitoring, } \\
\text { threshold intensity and the pain } \\
\text { intensity with the use of } \\
\text { Numerical Pain Rating Scale } \\
\text { (NPRS). There is a complete } \\
\text { sleep monitoring of the } \\
\text { episodes of bruxism with } \\
\text { intensity. }\end{array}$ & $\begin{array}{l}\text { There is a significant } \\
\text { decrease in the pain } \\
\text { level and grinding } \\
\text { intensity in both the } \\
\text { groups. There is a } \\
\text { minor improvement in } \\
\text { the treatment in } 8 \\
\text { weeks in comparison } \\
\text { to that of } 4 \text { weeks. As } \\
\text { it is more feasible to } \\
\text { conduct a short term } \\
\text { treatment in a clinical } \\
\text { setup thus } 1 \text { month of } \\
\text { contigent therapy to } \\
\text { reduce pain and } \\
\text { grinding intensity is } \\
\text { sufficient. }\end{array}$ \\
\hline $\begin{array}{ll}\text { Rathi } & \text { M, } \\
\text { et.al }^{35} & \end{array}$ & 2019 & $\begin{array}{lr}\text { Effect } & \text { of } \\
\text { kinesiotaping } & \text { on } \\
\text { pain and } & \text { muscle } \\
\text { activity } & \text { in } \\
\text { individuals } & \text { with } \\
\text { bruxism } & \end{array}$ & $\begin{array}{l}\text { To find effect of KT on } \\
\text { Pain and Muscle } \\
\text { activity in an } \\
\text { experimental group } \\
\text { with respect to the } \\
\text { control group. }\end{array}$ & 30 & $\begin{array}{l}\text { The outcome measures of pain } \\
\text { assessment by Numerical Pain } \\
\text { Rating Scale (NPRS) and } \\
\text { surface Electromyography for } \\
\text { recording the muscle activity. }\end{array}$ & $\begin{array}{l}\text { This study records the } \\
\text { pain intensity and } \\
\text { muscle activity after } \\
\text { the application of } \\
\text { kinesiotaping post } 24 \\
\text { hours treatment and } \\
\text { after } 48 \text { hours post } \\
\text { tape removal. The } \\
\text { outcome recorded a } \\
\text { significant reduction } \\
\text { in pain intensity and } \\
\text { muscle activity in } \\
\text { comparison with the } \\
\text { baseline and } 24 \text { hours } \\
\text { on removal of the } \\
\text { taping and } 48 \text { hours } \\
\text { post carryover period. }\end{array}$ \\
\hline
\end{tabular}

\section{DISCUSSION}

This Present study titled "Physiotherapy In Bruxism: A Scoping Review" was conducted in Pravara Institute of Medical Sciences, Loni. This scoping review is aimed to provide an overview of the recent physiotherapy treatment available in the treatment of Bruxism approaching on electrotherapy, manual therapy, biofeedback systems and other techniques. The articles were researched on search engines Like Pubmed, Google Scholar. Later the articles were selected according to inclusion and exclusion criteria. Furthermore, the Quality of the article were assessed PEDRO Scale. Thus, an impression of the articles is present.

Bruxism is defined as a parafunctional activity comprising of spasmodic non-functional gnashing, grinding, or clenching of teeth or involuntary rhythmic movement which may cause occlusal trauma. ${ }^{1}$ The symptoms include muscle and joint pain, pain while biting, morning muscle pain, stiffness, joint noises, headaches, jaw locking, hair line cracks, weared facets and periodontal changes. Additional there is stiffness and reduced mobility of the neck and shoulder.

Keskinruzgar A, et. al used kinesiotaping in treating bruxism where the observed reduction in the pain and increased joint range of motion and pressure pain threshold. It is equally effective as occlusal splint. ${ }^{28}$ Another study stated its efficacy in reducing its muscle stiffness and muscle thickness moreover drastic pain reduction in a short-termed treatment. It also provides better result when applied in accordance with Manual Therapy. ${ }^{30}$ One study concludes Kinesiotaping provides better than Myofascial trigger point release pain relief due to the local response which facilitates blood flow and lymph circulation. If the short-term effectiveness of this treatment is appreciable then the clinical use with other physical therapeutic exercises will provide better results. Both are effective in pain reduction. ${ }^{33}$ Another study states reduction in muscle activity as well. ${ }^{25}$ 
Gouw S, et. al stated that muscle stretching is not effective in relieving bruxism. Their study showed reduction in bruxism burst more and even episodes but not clinically significant. There was increase in the range motion also. They stated that long term treatment or other stretching than static stretch might provide a better result. ${ }^{27}$

Blasco- Bonora PM, et. al concluded that Dry needling technique has an effective reduction in pain, increases temporomandibular range of motion and pressure pain tolerance. ${ }^{29}$ Calisgan E, et. al stated Proprioceptive Neuromuscular Facilitation, Myofascial releasing maneuver and home exercises are effective in pain reduction, jaw mobility and oral habits. It provides facial control, functionality, relaxation and strengthening of the muscles also leading to benefits on physiological pain. Strengthening of neck and shoulders also facilitate the effects. ${ }^{31}$

Sya A, et.al concluded from their study that Low level LASER was effective in reducing the pain intensity and having a long term effect. LASER is applied on trigger points which cause vasodilatory mediators and decreased inflammatory response. ${ }^{32}$ Another study explained that it encourages pain reduction as changes in cell membrane permeability, vasodilation, and edema reduction, blocking the nerve fibers in response to the release of endogenous opioids (endorphins and enkephalin). Leading to a decrease in histamine and acetylcholine release and bradykinin synthesis. $^{36}$

Quaresma MC, et. al treated bruxism with contingent electrical stimulation. They observed significant reduction in pain and grinding intensity. There is no clear explanation as to how does stimulation reduce the pain more over due to the central neural alteration. There is decrease in the grinding episodes by the biofeedback mechanism. They advised administration of this treatment for 1 month as to more feasible. $^{34}$

One Study states that massage therapy reduces pain and quality of life in patients with sleep bruxism with the use of occlusal splints. ${ }^{37}$ Another study mentions a reduction in the muscular activity as well. ${ }^{38}$ A study concludes Exercise therapy with jaw mobility exercise and Psychological intervention reduces temporomandibular pain and jaw movement in parafunctional activity patients. ${ }^{39}$

\section{CONCLUSION}

Pain, muscle activity reduction and increase jaw mobility are the key symptoms to be focused on by physiotherapy management. Physiotherapy has recently provided different techniques like Kinesiotaping and dry needling effective, myofascial trigger point release in reducing pain in bruxism. There are modalities like contingent electrical stimulation which help in reducing episodes, low level laser therapy reduces bruxism pain. Exercises and relaxation and PNF techniques and massage therapy all help in increasing the range of motion, strengthening, pain reduction, better oral and sleep habits. More research needs to be done on effect of different stretching on bruxism. Overall a combination of this management can provide a better and quality treatment for Bruxism.

\section{ETHICAL APPROVAL}

An Ethical permission was obtained from Institutional Ethical Committee held on 16 December 2020 at Dr APJ Abdul Kalam College of Physiotherapy, Pavara Institute of Medical Sciences, Loni, Maharashtra, India- 413736.

Ethical Approval Ref. no:

BPT/INT/2020/36

Source of Funding: The source of funding for study is self.

\section{ACKNOWLEDGEMENTS}

Authors are thankful to all the participants who co-operated for the study and all those who directly and indirectly helped for the study.

\section{Conflict of Interest: None}




\section{REFERENCES}

1. Ella B, Ghorayeb I, Burbaud P, Guehl D. Bruxism in movement disorders: a comprehensive review. Journal of Prosthodontics. 2017 Oct;26(7):599-605.

2. Lavigne GJ, Khoury S, Abe S, Yamaguchi T, Raphael K. Bruxism physiology and pathology: an overview for clinicians. Journal of oral rehabilitation. 2008 Jul;35(7):476-94.

3. Shetty S, Pitti V, Babu CS, Kumar GS, Deepthi BC. Bruxism: a literature review. The Journal of Indian Prosthodontic Society. 2010 Sep;10(3):141-8.

4. Lobbezoo F, Ahlberg J, Glaros AG, Kato T, Koyano K, Lavigne GJ, De Leeuw R, Manfredini D, Svensson P, Winocur E. Bruxism defined and graded: an international consensus. Journal of oral rehabilitation. 2013 Jan;40(1):2-4.

5. Wetselaar P, Vermaire E, Lobbezoo F, Schuller AA. The prevalence of awake bruxism and sleep bruxism in the Dutch adult population. Journal of oral rehabilitation. 2019 Jul;46(7):617-23.

6. Soares LG, Costa IR, Brum Júnior JD, Cerqueira WS, Oliveira ES, Douglas de Oliveira DW, Gonçalves PF, Glória JC, Tavano KT, Flecha OD. Prevalence of bruxism in undergraduate students. CRANIO®. 2017 Sep 3;35(5):298-303.

7. Feu D, Catharino F, Quintão CC, Almeida MA. A systematic review of etiological and risk factors associated with bruxism. Journal of orthodontics. 2013 Jun;40(2):163-71.

8. Goldstein RE, Clark WA. The clinical management of awake bruxism. The Journal of the American Dental Association. 2017 Jun 1;148(6):387-91.

9. Taneja P, Nagpal R, Marya CM, Kataria S, Sahay V, Goyal D. Temporomandibular Disorders among Adolescents of Haryana, India: A Cross-sectional Study. International Journal of Clinical Pediatric Dentistry. 2019 Nov;12(6):500.

10. Rao SK, Bhat M, David J. Work, stress, and diurnal bruxism: a pilot study among information technology professionals in Bangalore City, India. International Journal of Dentistry. 2011 Jan 1;2011.
11. Johansson A, Omar R, Carlsson GE. Bruxism and prosthetic treatment: a critical review. Journal of prosthodontic research. 2011;55(3):127-36.

12. Kuhn M, Türp JC. Risk factors for bruxism. Swiss dental journal. 2018 Feb;128(2):118-24.

13. Lavigne GJ, Kato T, Kolta A, Sessle BJ. Neurobiological mechanisms involved in sleep bruxism. Critical Reviews in Oral Biology \& Medicine. 2003 Jan;14(1):3046.

14. Manfredini D, Serra-Negra J, Carboncini F, Lobbezoo F. Current Concepts of Bruxism. International Journal of Prosthodontics. 2017 Sep 1;30(5).

15. Castrillon EE, Exposto FG. Sleep Bruxism and Pain. Dental Clinics of North America. 2018 Aug 14;62(4):657-63.

16. Fernandes G, Franco AL, Aparecida de Godoi Gonçalves D, Geraldo Speciali J, Bigal ME, Camparis CM. Temporomandibular disorders, sleep bruxism, and primary headaches are mutually associated. Journal of orofacial pain. 2013 Jan 1;27(1).

17. Molina OF, dos Santos Jr J, Nelson SJ, Grossman E. Prevalence of modalities of headaches and bruxism among patients with craniomandibular disorder. CRANIO®. 1997 Oct 1;15(4):314-25.

18. Yilmaz G, Laine CM, Tinastepe N, Özyurt MG, Türker KS. Periodontal mechanoreceptors and bruxism at low bite forces. Archives of oral biology. $2019 \mathrm{Feb}$ 1;98:87-91.

19. Palinkas M, De Luca Canto G, Rodrigues LA, Bataglion C, Siéssere S, Semprini M, Regalo SC. Comparative capabilities of clinical assessment, diagnostic criteria, and polysomnography in detecting sleep bruxism. Journal of Clinical Sleep Medicine. 2015 Nov 15;11(11):1319-25.

20. Castroflorio T, Deregibus A, Bargellini A, Debernardi C, Manfredini D. Detection of sleep bruxism: comparison between an electromyographic and electrocardiographic portable holter and polysomnography. Journal of oral rehabilitation. 2014 Mar;41(3):163-9.

21. Doering S, Boeckmann JA, Hugger S, Young P. Ambulatory polysomnography 
for the assessment of sleep bruxism. Journal of oral rehabilitation. 2008 Aug;35(8):572-6.

22. Amorim CS, Santo AS, Sommer M, Marques AP. Effect of Physical Therapy in Bruxism Treatment: A Systematic Review. Journal of manipulative and physiological therapeutics. 2018 Jun 1;41(5):389-404.

23. AL-Oudah GA, AL-Ameedee AH, ALAmeedee AA. Effect Of Chlordiazepoxide Oral Tablet On Oral Recurrent Bruxism, A Clinical Trial Human Study. Systematic Reviews in Pharmacy. 2021;12(1):921-4.

24. Chisini LA, San Martin AS, Cademartori MG, Boscato N, Correa MB, Goettems ML. Interventions to reduce bruxism in children and adolescents: a systematic scoping review and critical reflection. European journal of pediatrics. 2020 Feb;179(2):177-89.

25. Craane B, Dijkstra PU, Stappaerts K, De Laat A. One-year evaluation of the effect of physical therapy for masticatory muscle pain: a randomized controlled trial. European Journal of Pain. 2012 May;16(5):737-47.

26. de Morton NA. The PEDro scale is a valid measure of the methodological quality of clinical trials: a demographic study. Australian Journal of Physiotherapy. 2009 Jan 1;55(2):129-33.

27. Gouw S, de Wijer A, Kalaykova SI, Creugers NH. Masticatory muscle stretching for the management of sleep bruxism: A randomised controlled trial. Journal of oral rehabilitation. 2018 Oct;45(10):770-6.

28. Keskinruzgar A, Kucuk AO, Yavuz GY, Koparal M, Caliskan ZG, Utkun M. Comparison of kinesio taping and occlusal splint in the management of myofascial pain in patients with sleep bruxism. Journal of back and musculoskeletal rehabilitation. 2019 Jan 1;32(1):1-6.

29. Blasco-Bonora PM, Martín-PintadoZugasti A. Effects of myofascial trigger point dry needling in patients with sleep bruxism and temporomandibular disorders: a prospective case series. Acupuncture in Medicine. 2017 Feb;35(1):69-74.
30. Yazici G, Kafa N, Kolsuz ME, VolkanYazici M, Evli C, Orhan K. Evaluation of single session physical therapy methods in bruxism patients using shear wave ultrasonography. CRANIO®. 2020 Aug 27:1-7.

31. Calisgan E, Talu B, Altun O, Dedeoglu N, Duman B. The effects of proprioceptive neuromuscular facilitation, myofascial releasing maneuvers and home exercises on pain and jaw function in patients with bruxism. Medicine. 2018;7(3):617-21.

32. SYa A, AMMb G, SNc K. The Effect of Low Level LASER Therapy, BOTAX, and Occlusal Splints in Treatment of Muscle Pain of Bruxism using Electromyogram.

33. Lietz-Kijak D, Kopacz Ł, Ardan R, Grzegocka M, Kijak E. Assessment of the short-term effectiveness of Kinesiotaping and trigger points release used in functional disorders of the masticatory muscles. Pain Research and Management. 2018 May 10;2018.

34. Quaresma MC, Crispim P, Luis H, Marques D, Caramês J. Effect of contingent electrical stimulation in sleep bruxism-a randomized clinical trial.

35. Rathi M, Keniya N, Palekar TJ. Effect of Kinesio-Taping on pain and muscle activity in individuals with Bruxism. Int $\mathbf{J}$ Basic Appl Res. 2019;9(6):899-909.

36. Pessoa DR, Costa DR, Prianti BD, Costa DR, Delpasso CA, Arisawa EÂ, Nicolau RA. Association of facial massage, dry needling, and laser therapy in Temporomandibular Disorder: case report. InCodas 2018 (Vol. 30, No. 6). Sociedade Brasileira de Fonoaudiologia.

37. de Paula Gomes CA, El-Hage Y, Amaral AP, Herpich CM, Politti F, KalilBussadori S, de Oliveira Gonzalez $\mathrm{T}$, Biasotto-Gonzalez DA. Effects of massage therapy and occlusal splint usage on quality of life and pain in individuals with sleep bruxism: a randomized controlled trial. Journal of the Japanese Physical Therapy Association. 2015;18(1):1-6.

38. de Paula Gomes CA, El Hage Y, Amaral AP, Politti F, Biasotto-Gonzalez DA. Effects of massage therapy and occlusal 
splint therapy on electromyographic activity and the intensity of signs and symptoms in individuals with temporomandibular disorder and sleep bruxism: a randomized clinical trial. Chiropractic \& manual therapies. 2014 Dec;22(1):1-7.

39. Makino I, Arai YC, Aono S, Hayashi K, Morimoto A, Nishihara M, Ikemoto T, Inoue $\mathrm{S}$, Mizutani $\mathrm{M}$, Matsubara $\mathrm{T}$, Ushida $\mathrm{T}$. The effects of exercise therapy for the improvement of jaw movement and psychological intervention to reduce parafunctional activities on chronic pain in the craniocervical region. Pain Practice. 2014 Jun;14(5):413-8.

How to cite this article: Savla K, Vardhan V, Aage D. Physiotherapy in bruxism: a scoping review. Int J Health Sci Res. 2021; 11(6): 115-125. DOI: https://doi.org/10.52403/ijhsr. 20210616 